\title{
Hypes en distantie - hoe te denken over aandeelhouders?
}

Arnoud W.A. Boot

Met alle onrust om ons heen - van financiële crisis tot economische crisis - lijkt er meer dan ooit behoefte aan reflectie en distantie. Als de laatste decennia ons iets geleerd hebben dan is dat we er niet veel mee opschieten als iedereen achter elkaar aan rent. En toch is dat wat is gebeurd. De internet bubble en de financiële crisis zijn ten ene malen veroorzaakt door zo maar achter elkaar aan te rennen.

Vaak is de druk om mee te doen aan de hype ondragelijk groot. Ik herinner mij dat de enige Zweedse bank die de Scandinavische bankencrisis van begin jaren negentig goed doorstond, Svenska Handelsbanken, net voor die crisis door de media werd afgeschilderd als loser. Zij verloor namelijk marktaandeel omdat ze niet meedeed aan de onroerend goed hype. Een paar maanden later werd ze plotseling als goddelijk beschouwd. Met het springen van de onroerend goed bubble lagen namelijk al haar concurrenten in puin en Svenska Handelsbanken was de lachende derde. Het kan verkeren.

En het is niet alleen dat we door hypes meegezogen worden in beslissingen die niet verstandig zijn, we vergeten ook vooruit te denken. Wat kan er morgen belangrijk zijn? Leun achterover, en denk eens na over wat een belangrijk is en misschien nu even geen aandacht heeft. Laat ik in deze column het goede voorbeeld geven en $\mathrm{U}$ vragen na te denken over de machtsverhoudingen in ondernemingsland, een onderwerp dat de komende jaren ongetwijfeld weer heel belangrijk wordt maar even uit het mediagezichtsveld is verdwenen.

Het gaat over de vraag of aandeelhouders 'zo maar' kunnen ingrijpen in het ondernemingsgebeuren om zo veranderingen af te dwingen. Hoezeer dit onderwerp door al het gerommel rond de financiële crisis ook op de achtergrond is geraakt, spoedig wordt het weer heel belangrijk.

Als je om je heen vraagt dan lijkt het aandeelhoudersdenken in een kwaad daglicht te staan. Aandeelhouders krijgen de schuld van wat is misgegaan bij ABN AMRO, en ook de financiële crisis wordt direct in verband gebracht met aandeelhouders. Het zouden de aandeelhouders zijn die in hun zoektocht naar steeds hogere rendementen bankbestuurders gek hebben gemaakt, en hebben aangezet tot onverantwoorde risico's. Voor zover er al aandacht voor is, lijkt de consensus van het moment om de macht van aandeelhouders in te dammen. Maar is dit een juiste analyse? Of is dit louter een reflectie van de waan van de dag? Laten we dit belangrijke onderwerp met een wat grotere distantie bespreken. De wetenschap biedt hiertoe een houvast.

Het aardige is dat de economische wetenschap hier al decennia naar kijkt. Al bijna tachtig jaar geleden - in 1932 om precies te zijn - benadrukten Adolf Berle en Gardiner Means dat de moderne onderneming een scheiding kent tussen eigendom en leiding, en dat dit allerlei conflicten kan geven tussen een management dat zijn eigen afwegingen maakt (en mogelijk een eigen agenda er op na houdt) en de wensen van de eigenaren, de aandeelhouders dus. Het meest evident is dat bij een beursgenoteerde onderneming waar de onderneming een groot aantal veelal anonieme aandeelhouders kent die op grote afstand staan van de onderneming. Dit geeft management potentieel veel macht hetgeen de fameuze econoom John Kenneth Galbraith er toe bracht om te spreken over managerial capitalism; niet aandeelhouders waren aan de macht maar managers.

In belangrijke bijdragen hebben Alchian \& Demsetz (1972) en Jensen \& Meckling (1976) het zogenaamde agency probleem tussen de moeilijk in toom te houden agent (het management) en de weinig krachtige principaal (de aandeelhouders) verder onder de aandacht gebracht. Het bracht Michael Jensen er zelfs toe om in 1989 in de Harvard Business Review te spreken over de Eclipse of the Public Corporation: beursgenoteerde ondernemingen zouden ten gronde gaan aan de expansiedrift van niet in te tomen management. Kern was de machteloosheid van de vaak 
zeer gespreide aandeelhouders. Er zou onvoldoende tegenwicht uitgaan van deze partij.

Het is verbijsterend om te zien hoe de discussie in het laatste decennium is omgedraaid. $\mathrm{Nu}$ wordt gesproken over te machtige aandeelhouders die hun brute kracht loslaten op ondernemingen en als roofdieren ondernemingen kapotmaken louter en alleen voor kortetermijngewin. Juist het management van beursgenoteerde ondernemingen - precies die ondernemingen waar volgens Berle \& Means, Galbraith en Jensen \& Meckling het management zo maar haar eigen weg kan gaan - zou nu zijn overgeleverd aan de willekeur van financiële markten en de daarin fungerende (gelegenheids)aandeelhouders.

Deze 180 graden omslag in het denken laat zien dat enige bezinning nodig is. Zien we het wel goed? Hebben de aandeelhouders werkelijk zo veel te vertellen, en hadden ze werkelijk zo weinig te vertellen in het verleden? Of is het dat de maatschappij en in haar kielzog het management van ondernemingen zich nadrukkelijk op financiële markten zijn gaan richten? Dit laatste lijkt het geval.

Aandelenkoersen en andere informatie uit de financiële markt staan dagelijks centraal in kranten en 24-uursmedia. Maar financiële markten, en de prijsvorming daarop, is hypegevoelig. Sommige dingen zijn op een bepaald moment 'hot', andere even niet. Ondernemingen worden overstelpt door consultants, analisten, investment bankers en niet te vergeten de al genoemde media om mee te doen aan de laatste hype. Deze druk op ondernemingen kan tot gevolg hebben dat het management zich van de kook laat brengen, zich niet in staat voelt om aan een strategie vast te houden, en zich onder druk gezet voelt door dit spel van de financiële markten. Als dan ook nog de directe beloning van het management wordt gekoppeld aan de aandelenkoers, en het management dus afgerekend wordt op de hypegevoelige waarderingen in de financiële markten, dan is de cirkel zo ongeveer rond.

Als dit zo is moeten we onze pijlen richten op bestuurders; deze laten zich telkens door hypes van het rechte pad afbrengen. Hoe kunnen we er voor zorgen dat bestuurders minder hypegevoelig worden $?^{1}$ In deze gedachtegang ligt de schuld misschien niet bij andeelhouders, maar bij bestuurders. De aandeelhouder de mond snoeren klinkt dan heel wat minder logisch.

Distantie is nodig zowel in het bestuur van ondernemingen - het moet minder hypegevoelig worden - als in onze analyse van, en aandacht voor vraagstukken: ze moeten minder onderhevig zijn aan de waan van de dag. De wetenschap kan bijdragen aan deze distantie, en juist in de hypegevoelige tijd waarin we leven is dat meer dan ooit nodig.

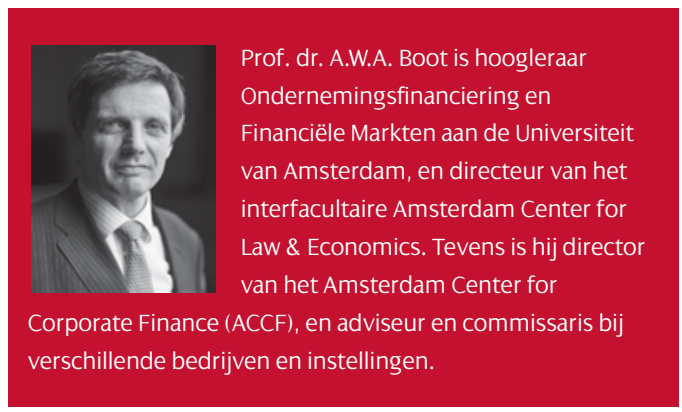

\section{Noten}

In mijn boek (Boot, 2010) ga ik hier nader

op in.

\section{Literatuur}

Alchian, A. en H. Demsetz (1972), Production, information costs, and economic organization, American Economic Review, vol. 62, pp. 777-795.

- Berle, A. en G. Means (1932), The modern corporation and private property, New York: MacMillan.
Boot, A.W.A. (2010), De ontwortelde onderneming, 2de druk, Van Gorcum. - Galbraith, J.K. (1967), The new industrial state, Princeton University Press.

- Jensen, M. (1989), The eclipse of the public corporation, Harvard Business Review. september/oktober, pp. 61-74.
Jensen, M.C. en W.H. Meckling (1976), Theory of the firm: Managerial behavior, agency costs and ownership structure, Journal of Financial Economics, vol. 3, no. 4, pp. 305-360. 